\title{
Decrease in the AP-2 DNA-Binding Activity and in the Protein Expression of AP- $2 \alpha$ and AP- $2 \beta$ in Frontal Cortex of Rats Treated with Lithium for 6 Weeks
}

\author{
Jagadeesh S Rao*,', Stanley I Rapoport' and Francesca Bosetti' \\ 'Brain Physiology and Metabolism Section, National Institute on Aging, National Institutes of Health, Bethesda, MD, USA
}

\begin{abstract}
Lithium chloride ( $\mathrm{LiCl}$ ), when fed to rats for 6 weeks, has been reported to decrease brain mRNA, protein, and activity levels of arachidonic acid (AA)-selective cytosolic phospholipase $A_{2}\left(C P L A_{2}\right)$, without affecting secretory sPLA $A_{2}$ or $C^{2}{ }^{2+}$-independent $i P L A_{2}$. We investigated whether transcription factors known to regulate $C P L A_{2}$ gene expression are modulated by chronic lithium treatment. Male Fischer-344 rats were fed a LiCl-containing diet for 6 weeks to produce a therapeutically relevant brain lithium concentration. Control animals were fed a LiCl-free diet. Using a gelshift assay, we found that LiCl significantly decreased activating protein 2 (AP-2)-binding activity, and protein levels of the AP- $2 \alpha$ and AP- $2 \beta$ but not of the AP-2 $\gamma$ subunits in the frontal cortex. Activating protein I (AP-I)binding activity was increased, whereas glucocorticoid response element, polyoma enhancer activator 3 , and nuclear factor kappa $\mathrm{B}$ DNA-binding activities were not changed significantly. Since both $\mathrm{CPLA} 2$ and AP-2 can be activated by protein kinase $C$ (PKC), we examined the frontal cortex protein levels of PKC $\alpha$ and PKC $\varepsilon$, as well as AA-dependent PKC activity. The protein levels of PKC $\alpha$ and PKC $\varepsilon$ were decreased significantly, as was AA-dependent PKC activity, in the lithium-treated compared to control rats. Our results suggest that the reported decrease in brain gene expression of $\mathrm{CPLA}_{2}$ by chronic lithium may be mediated by reduced AP-2 transcriptional activity, and that decreased expression of PKC $\alpha$ and PKC $\varepsilon$ contributes to lowering the AP-2 activity.

Neuropsychopharmacology (2005) 30, 2006-20 I3. doi:I0.I038/sj.npp. I300740; published online I3 April 2005
\end{abstract}

Keywords: brain; lithium; transcription factors; PKC; AP-2; AP-I

\section{INTRODUCTION}

Lithium is commonly used to treat bipolar disorder, but its precise mechanism of action is not clear. Evidence that lithium's mood-stabilizing effect requires weeks to develop (Jope and Williams, 1994; Manji et al, 1999) suggests alterations at the gene expression level (Hyman and Nestler, 1996), possibly mediated by the activation or inactivation of signaling cascades. It is well established that chronic, but not acute, treatment with lithium results in induction and altered expression of many genes in cells (Asghari et al, 1998) and in the intact rat brain (Bosetti et al, $2002 \mathrm{~b}$ ). Thus, it is possible that there is a chronic alteration in the steady-state activity of a given gene induced by prolonged lithium exposure. Another reason for delayed gene expression during lithium feeding to intact animals is the approximately 1 -week half-life for lithium to reach a

*Correspondence: Dr JS Rao, Brain Physiology and Metabolism Section, 9000 Rockville Pike, BIdg 9, IS 128, BPMS, National Institute on Aging, NIH, Bethesda, MD 20892, USA, Tel: + I 301594 3134; Fax: + I 30 I 402 0074, E-mail: jrao@mail.nih.gov

Received 5 October 2004; revised 7 March 2005; accepted 8 March 2005

Online publication: 9 March 2005 at http://www.acnp.org/citations/ Npp030905040472/default.pdf steady-state brain concentration, due to its slow penetration across the blood-brain barrier (Bosetti et al, 2002b). In this regard, lithium has been reported to target G-proteins (Li et al, 1993; Miki et al, 2001; Wang and Friedman, 1999), cyclic adenosine monophosphate (cAMP) (Mork, 1993; Mork and Geisler, 1995), protein kinase A (Mori et al, 1998), protein kinase C (PKC) (Manji et al, 1993, 1999, 1996; Soares et al, 2000) and its substrate MARCKS (Lenox et al, 1992; Watson and Lenox, 1996), glycogen synthase kinase-3 beta (GSK-3 $\beta$ ) (De Sarno et al, 2002), and activating protein 1 (AP-1) transcription factor (Ozaki and Chuang, 1997; Yuan et al, 1999). We reported that 6 weeks of lithium administration to rats, so as to produce therapeutically relevant plasma and brain lithium concentrations, resulted in reduced arachidonic acid (AA) turnover in brain phospholipids (Chang et al, 1996). In addition, chronic lithium reduced brain cytosolic phospholipase $\mathrm{A}_{2}\left(\mathrm{CPLA}_{2}\right)$ activity (Chang and Jones, 1998), protein and mRNA expression, and downregulated COX-2mediated AA metabolism to prostaglandin $\mathrm{E}_{2}$ (Bosetti et al, 2002a; Rintala et al, 1999). The effect on $\mathrm{CPLA}_{2}$ was selective, as secretory $\mathrm{sPLA}_{2}$ and $\mathrm{Ca}^{2+}$-independent $\mathrm{iPLA}_{2}$ were unaltered (Weerasinghe et al, 2004). Activation of cPLA $_{2}$ is mediated by $\mathrm{Ca}^{2+}$ and phosphorylation (Nemenoff et al, 1993). 
Protein kinase C (PKC) comprises a large family of phospholipid-dependent protein-serine/threonine kinase proteins, has 12 known subspecies in mammalian tissues, and can be activated by free $\mathrm{Ca}^{2+}$, phospholipids, or, in brain extracts, by AA (Koide et al, 1992). PKC also plays a role in the stimulus-mediated activation of $\mathrm{CPLA}_{2}$ (Xu et al, 2002), and lithium has been reported to influence PKC distribution and translocation in platelets of bipolar disorder patients (Friedman et al, 1993). Postmortem studies have also reported increased membrane-associated $\mathrm{PKC}$ and increased translocation of PKC isoforms from cytosol to membrane in response to phorbol 12-myristate 13-acetate in frontal cortex of brains from bipolar disorder compared with control subjects (Wang and Friedman, 1996). In the rat brain, chronic lithium treatment reduced cytosolic PKC $\alpha$ and PKC $\delta$ and increased membranal PKC $\zeta$ immunoreactivities, without altering total PKC activity (Wang et al, 2001). Chronic lithium also suppressed the translocation of PKC $\alpha$ and of other PKC isoforms in rat brain (Hahn and Friedman, 1999).

In this study, we further characterized the mechanism of downregulation of brain $\mathrm{CPLA}_{2}$ expression and activity by chronic lithium, by examining brain transcription factors recognized on the promoter region of the $\mathrm{CPLA}_{2}$ gene: AP-1, activation protein 2 (AP-2), glucocorticoid response element (GRE), polyoma enhancer activator 3 (PEA3), and nuclear factor kappa B (NF- $\kappa \mathrm{B})$ (Morri et al, 1994). A decreased DNA-binding activity of one or more of these factors might be responsible for the reported decrease in the brain $\mathrm{CPLA}_{2}$ mRNA level by lithium (Rintala et al, 1999). Since $\mathrm{CPLA}_{2}$ can be phosphorylated and activated by $\mathrm{PKC}$, we also determined protein levels of PKC $\alpha$ and PKC $\varepsilon$ as well as AA-dependent PKC activity, in frontal cortex of control and lithium-treated rats. We studied the frontal cortex because of evidence of decreased gray matter volume, and reduced neuronal and glial densities, in the frontal cortex of bipolar disorder patients (Lopez-Larson et al, 2002; Lyoo et al, 2004; Rajkowska, 2002).

\section{MATERIALS AND METHODS}

\section{Animals}

The study was approved by the National Institute of Child Health and Human Development (NICHD) Animal Care and Use Committee, in accordance with NIH guidelines on the care and use of laboratory animals. Eight adult male Fischer F-344 rats (200-250 g) were given $\mathrm{LiCl}$ at $1.70 \mathrm{~g} / \mathrm{kg}$ in their chow (Teklad, Madison, WI, USA) for 4 weeks, followed by chow (Teklad) containing $\mathrm{LiCl}$ at $2.55 \mathrm{~g} / \mathrm{kg}$ for another 2 weeks (Chang et al, 1996).

To prevent hyponatremia, water and $\mathrm{NaCl}$ solution (450 mM) were made available to all animals. This feeding regimen produces therapeutically relevant plasma and brain lithium concentrations of $\sim 0.8 \mathrm{mM}$ (Bosetti et al, 2002b). Control rats received a lithium-free diet for the same period. Rats were killed by an overdose of sodium pentobarbital $(100 \mathrm{mg} / \mathrm{kg}$, i.p.). The brains were rapidly excised and the frontal cortex was dissected, frozen in 2-methylbutane at $-50^{\circ} \mathrm{C}$ and stored at $-80^{\circ} \mathrm{C}$ until use.

\section{Preparation of Cytosolic and Nuclear Extracts from Rat Frontal Cortex}

Cytoplasmic and nuclear extracts were prepared from frontal cortex of control and lithium-treated rats, as described (Lahiri, 1998). Briefly, tissue was homogenized in $10 \mathrm{mM}$ HEPES, pH 7.9, $0.1 \mathrm{mM}$ EDTA, $0.1 \mathrm{mM}$ EGTA, $1 \mathrm{mM}$ DTT, $10 \mathrm{mM} \mathrm{KCl}$ buffer with a cocktail of protease inhibitors (Roche, Indianapolis, IN) using a Teflon-glass homogenizer. After adding $0.5 \%$ NP-40, five additional strokes of homogenization were performed. The suspension was incubated for $10 \mathrm{~min}$ on ice, and then centrifuged at $13000 \mathrm{~g}$ for $1 \mathrm{~min}$ at $4{ }^{\circ} \mathrm{C}$. The supernatant contained mostly cytoplasmic constituents. To the nuclear pellet, solution $\mathrm{B}$ (20 mM HEPES, pH 7.9, 1 mM EDTA, 1 mM EGTA, $1 \mathrm{mM}$ DTT, $0.4 \mathrm{M} \mathrm{NaCl}$ ) with a cocktail of protease inhibitors (Roche) was added. Tubes were mixed and placed on a small rotatory shaker for $30 \mathrm{~min}$. Finally, the mixture was centrifuged at $13000 \mathrm{~g}$ for $3 \mathrm{~min}$ at $4{ }^{\circ} \mathrm{C}$. The supernatant containing the proteins from the nuclear extracts was transferred to a fresh tube. The protein concentrations of cytoplasmic and nuclear extracts were determined using Bio-Rad protein Reagent (Bio-Rad, Hercules, CA).

\section{Electrophoretic Mobility Shift Assay (EMSA)}

A gelshift assay was performed with $15 \mu \mathrm{g}$ of nuclear extract, incubated with a nonradioactive $(10 \mathrm{ng})$ biotin-labeled DNA oligo consensus (Panomics, Redwood city, CA) in gelshift buffer (10 mM Tris- $\mathrm{HCl}, \mathrm{pH} 7.5,50 \mathrm{mM} \mathrm{NaCl}, 1 \mathrm{mM} \mathrm{MgCl}_{2}$, $0.5 \mathrm{mM}$ EDTA, $0.5 \mathrm{mM}$ DTT, $4 \%$ glycerol, and $50 \mu \mathrm{g} / \mathrm{ml}$ poly $\mathrm{dI}: \mathrm{dC}$ ) for $30 \mathrm{~min}$ on ice. The DNA-protein complex was separated on 5\% TBE gel and electrophoretically transferred to a nylon membrane. Biotin-labeled oligonucleotide complexes were visualized using a streptavidin-HRP conjugate coupled with chemiluminescence on X-ray film (Kodak, Rochester, NY). The following oligonucleotide sequences were used for the gelshift assay: AP-1: CGCTTGATGAGTCAGCCGGAA; NF- $\kappa$ B: AGTTGAGGGG ACTTTCCCGGC; AP-2: GATCGAACTGACCGCCCGCGG CCCGT, and PEA3: GATCT CGAGCAGGAAGTTCGA. The specificity of each transcription factor was determined by using 100 times excess unlabeled probe with a fixed amount of biotin-labeled DNA oligo consensus (10 ng) and nuclear extracts $(15 \mu \mathrm{g})$. All the gelshift assay experiments were carried out twice with eight independent samples for each group. Optical densities of gelshift bands were quantified using Alpha Innotech software (Alpha Innotech, San Leandro, California). Values were expressed as percent of control.

\section{Western Blot Analysis}

In total, $60 \mu \mathrm{g}$ of cellular or nuclear extract was separated on $10 \%$ SDS-polyacrylamide gels (Bio-Rad). Following SDSPAGE, proteins were electrophoretically transferred to a nitrocellulose membrane. After overnight blocking in PBS containing 5\% nonfat dried milk and $0.1 \%$ Tween-20, blots were incubated overnight with $1: 1000$ specific primary antibodies for AP-2 $\alpha$, AP-2 $\beta$, orAP-2 $\gamma$ (Santa Cruz, Santa Cruz, CA). PKC $\alpha$ and $\varepsilon$ protein levels were also determined in cytoplasmic extracts from control and lithium-treated 
groups using specific primary antibodies for PKC $\alpha$ and PKC $\varepsilon$ ( $1: 1000$, Santa Cruz), followed by HRP-conjugated secondary antibodies (Bio-Rad). Blots were visualized using a chemiluminescence reaction (Amersham, Piscataway, NJ) on X-ray film (XAR-5, Kodak). All the experiments were carried out twice with eight independent samples for each group. Optical densities of the immunoblots were measured using Alpha Innotech software (Alpha Innotech). Optical densities were normalized to $\beta$-actin (Sigma, St Louis, MO) to correct for differences in loading. Data were expressed as percent of control.

\section{Total RNA Isolation and Real-Time RT-PCR}

Total RNA was isolated from control and lithium-treated brain samples using an RNeasy mini kit for brain and lipid tissue (Qiagen, Valencia CA). cDNA was prepared from total RNA using a high-capacity cDNA Archive kit (Applied Biosystems, Foster City, CA). Brain AP-2 $\alpha$ and AP-2 $\beta$ mRNA levels in control and lithium-treated animals were measured by real-time quantitative RT-PCR, using ABI PRISM 7000 sequence detection system (Applied Biosystems). Specific primers and probes for AP-2 $\alpha$ and AP-2 $\beta$ were purchased from the available Assays-on-Demand (Applied Biosystems), which consist of a $20 \times \operatorname{mix}$ of unlabeled PCR primers and Taqman minor groove binder (MGB) probe (FAM dye-labeled). The fold change in gene expression was determined by using the $\Delta \Delta C_{\mathrm{T}}$ method (Livak and Schmittgen, 2001). Data were expressed as the relative level of the target gene (AP-2 $\alpha-\mathrm{AP}-2 \beta$ ) in the lithium-treated animals normalized to the endogenous control ( $\beta$-globulin) and relative to the control rats (calibrator), as previously described (Ghelardoni et al, 2004). Each sample was assayed in triplicate and all the experiments were carried out twice with six independent samples. Data were expressed as relative to expression of controls.

\section{PKC Activity}

Basal and AA-dependent PKC activities were measured in brain cytoplasmic extracts $(10 \mu \mathrm{g})$ using a nonradioactive PKC kinase assay kit (Stressgen Bioreagents, Victoria, BC, Canada). This is an enzyme linked immunoabsorbent assay that uses a specific synthetic peptide as a substrate for PKC and a polyclonal antibody that recognizes the phosphorylated form of the substrate. Briefly, total cytoplasmic extract protein $(10 \mu \mathrm{g})$ was incubated with immobilized substrate in the absence and presence of $40 \mu \mathrm{M}$ AA. The reaction was initiated by adding ATP. The kinase reaction was terminated after $60 \mathrm{~min}$ of incubation, and then a phosphospecific substrate antibody was added. A peroxidaseconjugated secondary antibody subsequently was bound to the phosphospecific antibody. The assay was developed by adding the tetramethylbenzidine substrate (TMB) and intensity of the color was measured at $450 \mathrm{~nm}$. The intensity of color development is proportional to phosphotransferase activity. Individual sample reading was corrected by subtracting the corresponding blank reading (without cytoplasmic extracts) and dividing by the log $\mu \mathrm{g}$ of protein. Seven to eight independent samples were used in each group and each sample was assayed in triplicate and experiments carried out twice. All the values within the intra- and interassay coefficient of variation of $<10 \%$ were taken for calculating PKC activities. Values were expressed in relative $\mathrm{PKC}$ activity.

\section{Statistical Analysis}

Data were expressed as mean \pm SEM. Statistical significance was calculated using a two-tailed unpaired $t$-test, and set as $p<0.05$.

\section{RESULTS}

\section{Physiological Parameters}

Rats fed with lithium diet showed a significant decrease in mean body weight compared to control rats $(240 \pm 5 \mathrm{~g} v \mathrm{~s}$ $281 \pm 6 \mathrm{~g}, p<0.0001, n=16)$. This effect has been ascribed to uncompensated lithium-induced polyuria (Teixeira and Karniol, 1982). Lithium feeding did not affect mean body temperature, heart rate, or arterial blood $\mathrm{pH}, \mathrm{pO}_{2}, \mathrm{pCO}_{2}$, or blood pressure (data not shown).

\section{The Effect of Lithium on the DNA-Binding Activity of the Transcription Factors that Regulate $\mathrm{CPLA}_{2}$ Expression}

To determine whether the reported downregulation of brain $\mathrm{cPLA}_{2}$ mRNA by chronic lithium occurs at the level of transcription, we measured DNA-binding activities of different transcription factors that are known to regulate cPLA $_{2}$ gene transcription. Lithium significantly decreased by $42 \%$ the binding of nuclear proteins to the AP-2 consensus sequence $(p<0.05)$ (Figure 1a). In contrast, it increased AP-1 DNA-binding activity by $66 \% \quad(p<0.05)$ (Figure 1b), consistent with a previous report (Ozaki and Chuang, 1997). Binding activities of GRE, PEA3, or NF- $\kappa \mathrm{B}$ DNA were not significantly changed (Figure 1c). As shown in Figure 2, in the presence of an excess (100 times) of unlabeled specific oligonucleotides, the binding of labeled oligonucleotides was blocked, indicating the specificity of DNA-binding activities.

\section{The Effect of Lithium on AP-2 $\alpha$, AP-2 $\beta$, and AP-2 $\gamma$ Expression}

To further investigate whether the changes in brain AP-2 DNA-binding activities in lithium-treated animals were due to a change in protein levels of AP-2 subunits, the protein levels of AP- $2 \alpha$ and $\beta$ were measured by Western blotting. Chronic lithium decreased the protein level of AP- $2 \alpha$ in both cytoplasmic and nuclear extracts (by 47 and 38\%; respectively, $p<0.05$ ) (Figure $3 \mathrm{a}$ ). The protein level of AP-2 $\beta$ also was reduced in the two extracts, by 44 and $46 \%$, respectively $(p<0.05)$ (Figure $3 b$ ), compared to control levels. In contrast, the protein level of the AP-2 $\gamma$ subunit was not significantly changed by lithium (Figure $3 \mathrm{c}$ ).

To determine whether the changes in protein levels of AP$2 \alpha$ and AP- $2 \beta$ in lithium-treated rats were due to changes in their mRNA expression, mRNA levels of AP- $2 \alpha$ and AP-2 $\beta$ were measured using real-time RT-PCR. We did not find any statistically significant change in the mRNA level of 
a
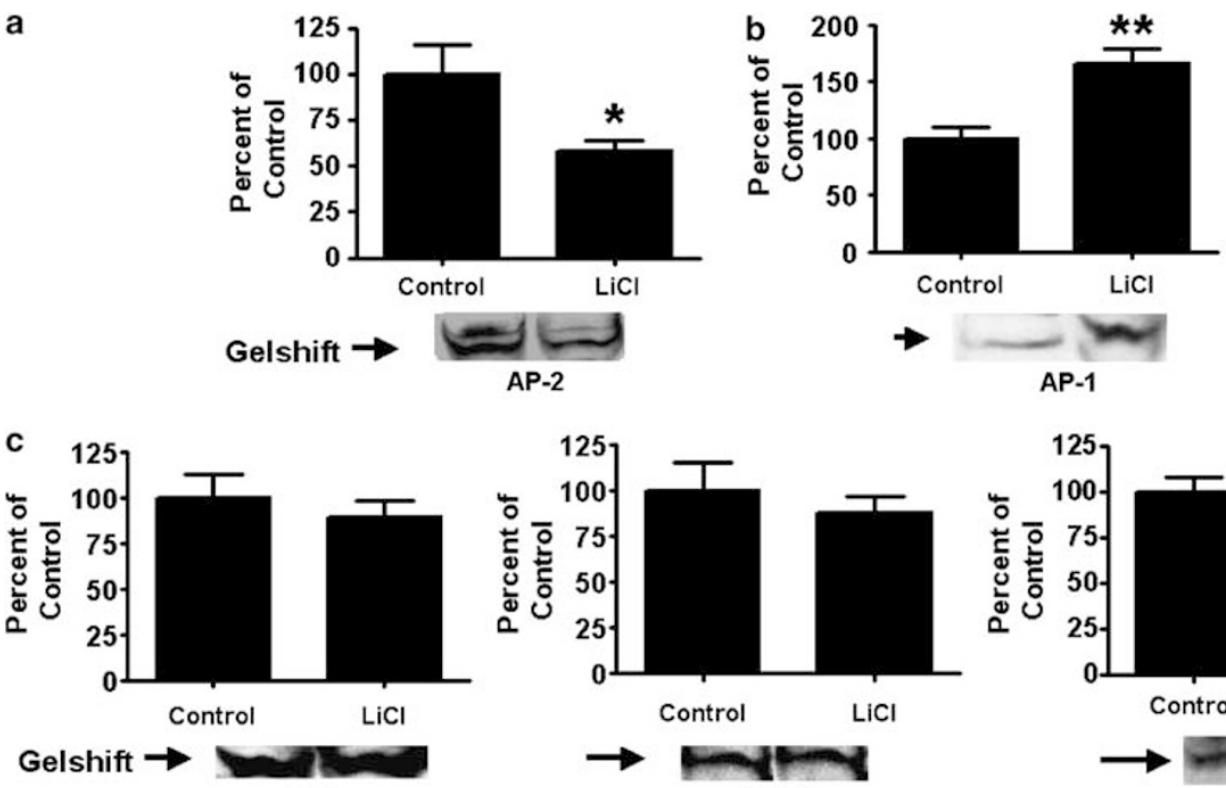

GRE

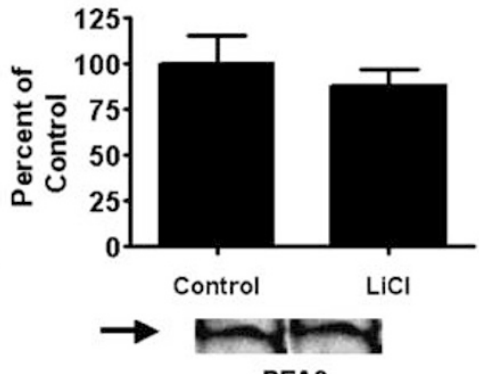

PEA3
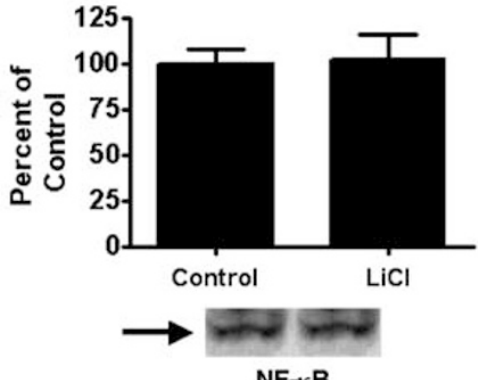

Figure I Representative gelshift bands of AP-2 (a), AP-I (b), GRE, PEA3, and NF- $\kappa$ B (c) in frontal cortex from control and lithium-treated rats. DNAbinding activity was measured in brain nuclear extracts, as described in the Materials and Methods. Data are mean \pm SEM expressed as percent of controls, and compared using an unpaired $t$-test $\left(n=8\right.$ independent samples). ${ }^{*} p<0.05 ; * * 0.01$.

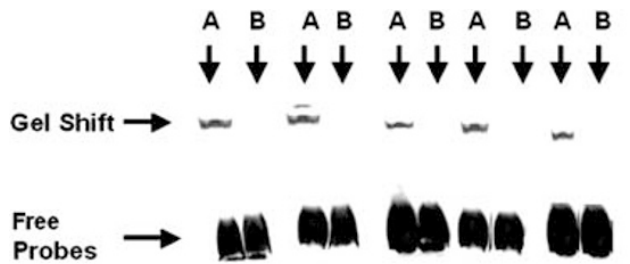

AP-1 AP-2 GRE NF-kB PEA3

Figure 2 DNA-binding activities for AP-I, AP-2, GRE, NF- $\kappa$ B, and PEA3 in rat frontal cortex. Specificity of DNA-protein-binding activities was tested in nuclear extracts in the absence $(A)$ and presence $(B)$ of excess ( 100 times) unlabeled probe, as described in the Materials and Methods. The unlabeled probe blocked the binding of labeled probe and decreased the gelshift.

either AP- $2 \alpha(0.89 \pm 0.21)$ or AP-2 $\beta(1.0 \pm 0.22)$ in lithiumtreated animals compared to controls (AP-2 $\alpha ; 1.0 \pm 0.10$; AP-2 $\beta ; 1.0 \pm 0.18)$.

\section{The Effect of Lithium on PKC Expression and Activity}

Since $\mathrm{CPLA}_{2}$ and AP-2 can be activated by phosphorylation by $\mathrm{PKC}$, which in turn can be activated by AA (Koide et al, 1992), we determined whether the reported downregulation by chronic lithium of brain $\mathrm{PLA}_{2}$ activity (Chang and Jones, $1998)$ is accompanied by a change in PKC activity or in the protein level of PKC $\alpha$ or PKC $\varepsilon$. Chronic lithium decreased the protein levels of PKC $\alpha$ by $35 \%(p<0.01)$ (Figure $4 \mathrm{a}$ ) and of PKC $\varepsilon$ by $27 \%(p<0.05)$ (Figure $4 \mathrm{~b})$ in frontal cortex compared to control levels. To determine whether the above changes in protein level had affected basal and AAdependent PKC activities, we also measured PKC activity in the presence and absence of AA. In pilot experiments, different concentrations of $\mathrm{AA}$ in the range $0-100 \mu \mathrm{M}(0,20$, $40,60,100 \mu \mathrm{M})$ were used to choose the optical AA concentration changing $\mathrm{PKC}$ activity. AA increased PKC activity in a dose-dependent manner with a threshold of $40 \mu \mathrm{M}$ (data not shown). As shown in Figure 4c, total PKC activity in the presence of $40 \mu \mathrm{M}$ AA was decreased by $35 \%$ $(p<0.001)$ in lithium-treated rats $(0.65 \pm 0.05)$ compared to controls $(1.0 \pm 0.02)$. However, PKC activity, measured in the absence of exogenous AA, was not significantly changed.

\section{DISCUSSION}

In this study, we examined transcription factors known to regulate $\mathrm{CPLA}_{2}$ gene expression in frontal cortex of rats treated for 6 weeks with lithium so as to produce a therapeutically relevant brain lithium concentration. We found a significant decrease in AP-2 DNA-binding activity in the lithium-treated compared with control rats. This change was accompanied by a significant decrease in the protein levels of AP- $2 \alpha$ and $\beta$ subunits, but not in their mRNA expression. Chronic lithium also did not alter the protein level of AP-2 $\gamma$. In contrast, AP- 1 DNA-binding activity was increased, whereas DNA-binding activities of other transcription factors on the promoter region of $\mathrm{CPLA}_{2}$ gene-GRE, PEA3, and NF- $\kappa \mathrm{B}$ - were not changed significantly. Chronic lithium decreased the protein level of PKC $\alpha$ and $\mathrm{PKC} \varepsilon$, and reduced AA-dependent PKC activity. Lithium-fed rats also showed a decrease in body weight, likely due to the lithium-induced polyuria, without a significant change in other measured physiological parameters.

Our results suggest that decreased AP-2 DNA-binding activity may be responsible for the reported downregulation 
a

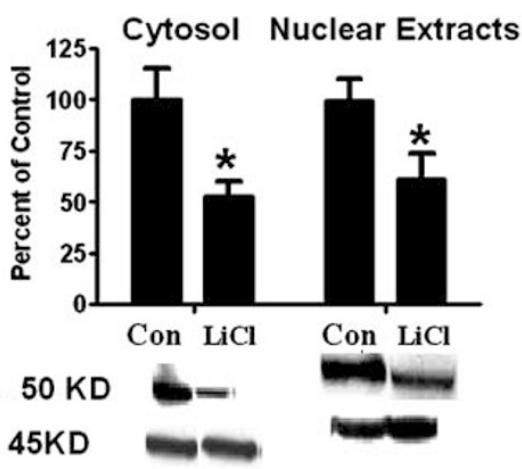

b

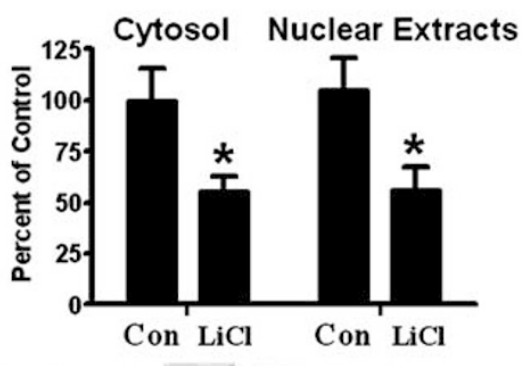

AP-2 $\beta \quad 50 \mathrm{KD}$

$\beta$-actin 45 KD

C

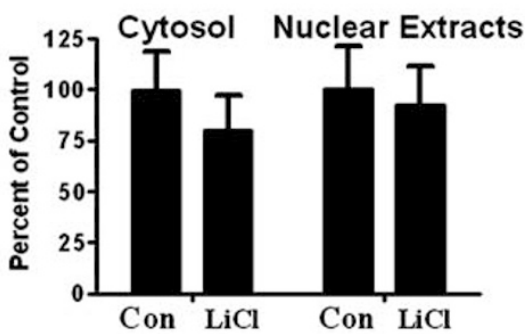

$\mathrm{AP}-2 \gamma 50 \mathrm{KD}$
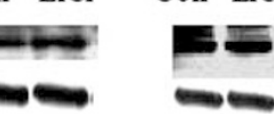

\section{$\beta$-actin $45 \mathrm{KD}$}

Figure 3 Cytosolic and nuclear protein levels of AP- $2 \alpha$ (a), AP- $2 \beta$ (b), and $\mathrm{AP}-2 \gamma$ (c) in frontal cortex from control and lithium-treated rats. Immunolabeling of cytoplasmic and nuclear AP-2 proteins was performed as described in the Materials and Methods. Data are ratios of optical density of each AP-2 isoform to that of $\beta$-actin, expressed as percent of control and are compared using an unpaired t-test (mean \pm SEM, $n=8$ independent samples, $\left.{ }^{*} p<0.05\right)$.

of brain gene and protein expression of $\mathrm{CPLA}_{2}$ by chronic lithium (Rintala et al, 1999). The results agree with a study in which 11 days of lithium treatment decreased protein binding to AP-2 DNA consensus in nuclear extracts of rat brain (Damberg et al, 2000). However, because in that study the protein levels of AP- $2 \alpha$ and $\beta$ were not changed, the decrease by lithium in AP- $2 \alpha$ or $\beta$ might be dose- and/or time-dependent. Since the mRNA levels of these subunits remained unchanged, it is possible that lithium's effect on AP-2 occurs at a post-transcriptional level. The decreased protein levels of AP- $2 \alpha$ and $\beta$ that we found after 6 weeks of lithium treatment could further contribute to the decreased AP-2 DNA-binding activity.

Activation of AP-2 requires phosphorylation of its subunits by PKC or PKA (Imagawa et al, 1987). Phos- a

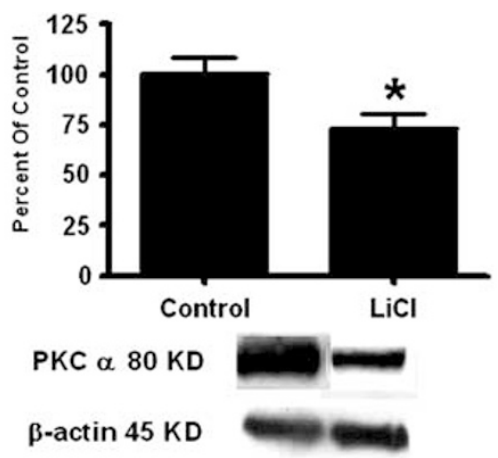

b
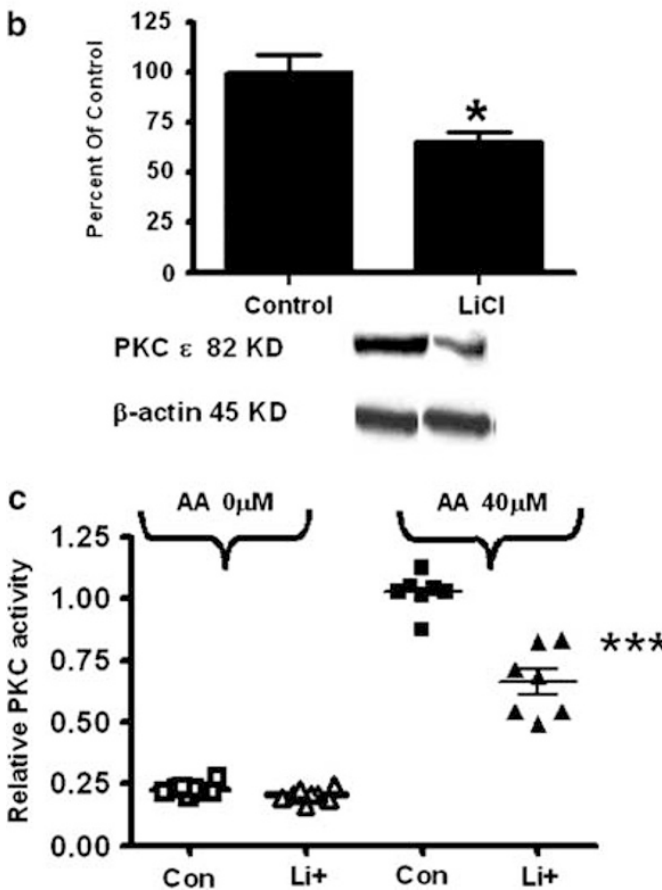

Figure 4 Protein expression of cytoplasmic PKC $\alpha$ (a) and PKC $\varepsilon$ (b), and PKC activity (c) in frontal cortex from control and lithium-treated rats. Immunolabeling of PKC $\alpha$ and PKC $\varepsilon$ was performed as described in the Materials and Methods. Data are the ratios of the optical densities of PKC $\alpha$ $(n=8)$ and PKC $\varepsilon(n=8)$ to that of $\beta$-actin in cytosolic fractions. Data are expressed as percent of control. Total PKC activity was measured in the absence (basal; 8 independent samples) and in the presence (activated) of $40 \mu$ M AA. Data in panel (c) are mean \pm SEM ( $n=7-8$ independent samples). Data are expressed as relative PKC activity and compared using an unpaired $t$-test. $* p<0.05$; $* * * * * 0.001$.

phorylated AP-2 subunits translocate to the nucleus, where they recognize a specific AP-2-binding sequence on chromatin to initiate transcription. Since PKC is involved in the activation of both $\mathrm{CPLA}_{2}$ and AP-2, both of which are downregulated by lithium, we measured PKC activity in the absence of exogenous AA as well after adding $40 \mu \mathrm{M}$ AA. $\mathrm{AA}$, which is released from cell membrane phospholipids by $\mathrm{PLA}_{2}$ enzymes, is involved in many physiological process including activation of $\mathrm{PKC} \alpha$ and $\mathrm{PKC} \varepsilon$ in rat brain (Koide et al, 1992). Ours is the first study to show a significant decrease in AA-stimulated PKC activation by chronic lithium treatment, without a change in basal (unstimulated) PKC activity. This finding agrees with our report that the 
phosphorylation state of rat brain $\mathrm{CPLA}_{2}$ under basal conditions was not changed significantly by chronic lithium (Weerasinghe et al, 2003).

Earlier studies indicated that chronic lithium treatment altered PKC isoforms in rat frontal cortex, without changing total tissue PKC activity (Wang et al, 2001). This absence of change in total PKC activity was ascribed to a high abundance of PKC $\gamma$, a neuron-specific PKC, which is the major contributor to total PKC activity, thus masking changes in activities of the other PKC isoforms (Wang et al, 2001). The lack of effect on basal activity by lithium that we observed in this study may be due to the contribution of activity by other PKC isoforms, which masked the changes in the PKC $\alpha$ and PKC $\varepsilon$ activities. In contrast to its effect on $\mathrm{PKC}$, chronic lithium is reported not to change cAMPdependent PKA activity in the cytosolic fraction of rat cortex (Jensen and Mork, 1997), suggesting that PKA may not be involved in lithium's effect on AP-2 activation.

Decreased brain expression of PKC $\alpha$ and PKC $\varepsilon$ and of AA-dependent PKC activity following chronic lithium may contribute to the downregulation of AP-2 DNA-binding activity. The decreases also may lead to a reduced stimulusmediated release of AA. This is supported by a report that prolonged exposure of mouse primary astrocytes to $100 \mathrm{nM}$ phorbol myristate acetate caused a time-dependent downregulation of $\mathrm{PKC} \alpha$ and $\mathrm{PKC} \varepsilon$, as well as of AA release (Xu et al, 2002). Another report, however, did not find any change in protein levels of PKC isoforms in frontal cortex of 3-week lithium-treated rats (Manji et al, 1996). The discrepancy might be due to differences in the Western blotting procedures or in the duration of lithium treatment ( 3 weeks vs our 6 weeks).

Rapid activation of $\mathrm{cPLA}_{2}$ through AA-stimulated $\mathrm{PKC}$ activation may play a role in cerebral ischemia and inflammation, where $\mathrm{CPLA}_{2}$ activity is elevated and $\mathrm{PKC}$ is altered (Manji et al, 1996; Saluja et al, 1999; Stella et al, 1997). In contrast, modification of gene expression may require hours to days. This might involve the downregulation by chronic lithium of $\mathrm{CPLA}_{2}$ gene expression via lithium's effects on AP-2, which also depend on PKC. In a fast response, PKC activates $\mathrm{CPLA}_{2}$ activity. $\mathrm{PKC}$ can be activated by diacylglycerol, calcium, and AA. PKC in turn activates the AP-2 transcription factor. Chronic lithium reduces protein levels of $\mathrm{PKC}$ and $\mathrm{AP}-2$ subunits in rat brain, which results in reduced AA-dependent $\mathrm{PKC}$ activity and AP-2 DNA binding. This may lead to a reduced expression of $\mathrm{CPLA}_{2}$

Our results suggest that chronic lithium decreased AAdependent PKC activity in the frontal cortex leading to reduced activation of AP-2, which in turn may downregulate $\mathrm{cPLA}_{2}$ gene expression (Rintala et al, 1999). This downregulation likely modifies neuronal signaling, considering $\mathrm{CPLA}_{2}$ 's role in several signal transduction pathways in brain (Sun et al, 2004). This effect also has clinical implications, as evidence indicates that PKC expression is upregulated in brains from patients with bipolar disorder (Hahn and Friedman, 1999; Wang and Friedman, 1996). PKC activation in bipolar disorder could trigger the activation of $\mathrm{CPLA}_{2}$ and increase AA release and metabolism, supporting the hypothesis of a 'hyperactive AA cascade' in bipolar disorder (Rapoport and Bosetti, 2002). Additionally, AP-2 has been implicated in neurodevelop- ment (Moser et al, 1997) and monoaminergic activity (Damberg et al, 2001).

The increase that we found in the AP-1 DNA-binding activity in the frontal cortex of chronic lithium-treated rats agrees with earlier reports (Asghari et al, 1998; Ozaki and Chuang, 1997; Yuan et al, 1999), and suggests that lithium independently modulates different transcription factors. The increase might be due to activation of c-Jun N-terminal kinases (Chen et al, 2003; Yuan et al, 1999), which phosphorylate one subunit of AP-1 (cJun-cFOS), or to inhibition of GSK-3 (Klein and Melton, 1996; Stambolic et al, 1996). GSK-3 $\beta$ phosphorylates c-Jun at three sites adjacent to its AP-1 consensus sequence binding domains, thereby reducing AP-1-binding activity (Lin et al, 1993). The upregulation of AP-1 activity, in turn, might affect expression of other genes whose transcription is controlled by the AP-1 family of transcription factors, including genes for neuropeptides, neurotrophins, receptors, enzymes involved in neurotransmitter biosynthesis, and bcl-2 (Brunello, 2004).

The absence of a lithium effect on the DNA-binding activities of GRE, PEA3, and NF- $\kappa \mathrm{B}$ suggests that these transcription factors are not involved in the downregulation of $\mathrm{cPLA}_{2}$ gene expression by chronic lithium. It remains unclear whether decreased AP-2 DNA-binding activity is solely responsible for the downregulation of $\mathrm{CPLA}_{2}$ gene expression, or if there is crosstalk between increased AP-1 and decreased AP-2 in modulating $\mathrm{CPLA}_{2}$ gene expression. It also is possible that lithium decreases cPLA $_{2}$ mRNA by affecting its stability, and studies in cultured cells may clarify this issue. Additionally, studying single cells might clarify the direct involvement of AP-2 in regulating $\mathrm{CPLA}_{2}$ gene expression in lithium-treated neuronal cell lines.

There is evidence that a clinically relevant lithium level in plasma produces beneficial effects in animal models of depression (Angelucci et al, 2003). Lithium fed 42 days to Flinders-sensitive line rats produced significant changes in brain levels of NGF, BDNF, and GDNF compared to Flinders-resistant line rats (Angelucci et al, 2003). Changes in BDNF can rectify behavioral deficits in an animal model of depression in learned helplessness and in the forced swim test (Siuciak et al, 1997). Chronic lithium also corrects disrupted circadian clocks (Abe et al, 2000; Schibler, 1998) and can affect the endocrine system while decreasing CRF1 mRNA in the amygdala and frontal cortex (Gilmor et al, 2003). Overall, studies suggest that chronic lithium can alter many neurochemical and endocrinological pathways, which modulate neuronal plasticity, and normalize behavioral defects in animal models.

\section{ACKNOWLEDGEMENTS}

This work was entirely supported by the Intramural Research Program of the National Institute on Aging, National Institutes of Health.

\section{REFERENCES}

Abe M, Herzog ED, Block GD (2000). Lithium lengthens the circadian period of individual suprachiasmatic nucleus neurons. NeuroReport 11: 3261-3264. 
Angelucci F, Aloe L, Jimenez-Vasquez P, Mathe AA (2003). Lithium treatment alters brain concentrations of nerve growth factor, brain-derived neurotrophic factor and glial cell linederived neurotrophic factor in a rat model of depression. Int $J$ Neuropsychopharmacol 6: 225-231.

Asghari V, Wang JF, Reiach JS, Young LT (1998). Differential effects of mood stabilizers on Fos/Jun proteins and AP-1 DNA binding activity in human neuroblastoma SH-SY5Y cells. Brain Res Mol Brain Res 58: 95-102.

Bosetti F, Rintala J, Seemann R, Rosenberger TA, Contreras MA, Rapoport SI et al (2002a). Chronic lithium downregulates cyclooxygenase- 2 activity and prostaglandin $\mathrm{E}(2)$ concentration in rat brain. Mol Psychiatry 7: 845-850.

Bosetti F, Seemann R, Bell JM, Zahorchak R, Friedman E, Rapoport SI et al (2002b). Analysis of gene expression with cDNA microarrays in rat brain after 7 and 42 days of oral lithium administration. Brain Res Bull 57: 205-209.

Brunello N (2004). Mood stabilizers: protecting the mood...protecting the brain. J Affect Disord 79(Suppl 1): S15-S20.

Chang MC, Grange E, Rabin O, Bell JM, Allen DD, Rapoport SI (1996). Lithium decreases turnover of arachidonate in several brain phospholipids. Neurosci Lett 220: 171-174.

Chang MC, Jones CR (1998). Chronic lithium treatment decreases brain phospholipase A2 activity. Neurochem Res 23: 887-892.

Chen RW, Qin ZH, Ren M, Kanai H, Chalecka-Franaszek E, Leeds $\mathrm{P}$ et al (2003). Regulation of c-Jun N-terminal kinase, p38 kinase and AP-1 DNA binding in cultured brain neurons: roles in glutamate excitotoxicity and lithium neuroprotection. $J$ Neurochem 84: 566-575.

Damberg M, Ekblom J, Oreland L (2000). Chronic pharmacological treatment with certain antidepressants alters the expression and DNA-binding activity of transcription factor AP-2. Life Sci 68: 669-678.

Damberg M, Eller M, Tonissaar M, Oreland L, Harro J (2001). Levels of transcription factors AP-2alpha and AP-2beta in the brainstem are correlated to monoamine turnover in the rat forebrain. Neurosci Lett 313: 102-104.

De Sarno P, Li X, Jope RS (2002). Regulation of Akt and glycogen synthase kinase-3 beta phosphorylation by sodium valproate and lithium. Neuropharmacology 43: 1158-1164.

Friedman E, Hoau Yan W, Levinson D, Connell TA, Singh H (1993). Altered platelet protein kinase C activity in bipolar affective disorder, manic episode. Biol Psychiatry 33: 520-525.

Ghelardoni S, Tomita YA, Bell JM, Rapoport SI, Bosetti F (2004). Chronic carbamazepine selectively downregulates cytosolic phospholipase $\mathrm{A}(2)$ expression and cyclooxygenase activity in rat brain. Biol Psychiatry 56: 248-254.

Gilmor ML, Skelton KH, Nemeroff CB, Owens MJ (2003). The effects of chronic treatment with the mood stabilizers valproic acid and lithium on corticotropin-releasing factor neuronal systems. J Pharmacol Exp Ther 305: 434-439.

Hahn CG, Friedman E (1999). Abnormalities in protein kinase C signaling and the pathophysiology of bipolar disorder. Bipolar Disord 1: 81-86.

Hyman SE, Nestler EJ (1996). Initiation and adaptation: a paradigm for understanding psychotropic drug action. Am J Psychiatry 153: 151-162.

Imagawa M, Chiu R, Karin M (1987). Transcription factor AP-2 mediates induction by two different signal-transduction pathways: protein kinase C and cAMP. Cell 51: 251-260.

Jensen JB, Mork A (1997). Altered protein phosphorylation in the rat brain following chronic lithium and carbamazepine treatments. Eur Neuropsychopharmacol 7: 173-179.

Jope RS, Williams MB (1994). Lithium and brain signal transduction systems. Biochem Pharmacol 47: 429-441.

Klein PS, Melton DA (1996). A molecular mechanism for the effect of lithium on development. Proc Natl Acad Sci USA 93: 8455-8459.
Koide H, Ogita K, Kikkawa U, Nishizuka Y (1992). Isolation and characterization of the epsilon subspecies of protein kinase $\mathrm{C}$ from rat brain. Proc Natl Acad Sci USA 89: 1149-1153.

Lahiri DK (1998). An region upstream of the gene promoter for the beta-amyloid precursor protein interacts with proteins from nuclear extracts of the human brain and PC12 cells. Brain Res Mol Brain Res 58: 112-122.

Lenox RH, Watson DG, Patel J, Ellis J (1992). Chronic lithium administration alters a prominent $\mathrm{PKC}$ substrate in rat hippocampus. Brain Res 570: 333-340.

Li PP, Young LT, Tam YK, Sibony D, Warsh JJ (1993). Effects of chronic lithium and carbamazepine treatment on G-protein subunit expression in rat cerebral cortex. Biol Psychiatry 34: 162-170.

Lin A, Smeal T, Binetruy B, Deng T, Chambard JC, Karin M (1993). Control of AP-1 activity by signal transduction cascades. Adv Sec Mess Phosph Res 28: 255-260.

Livak KJ, Schmittgen TD (2001). Analysis of relative gene expression data using real-time quantitative $\mathrm{PCR}$ and the 2(-Delta Delta C(T)) Method. Methods 25: 402-408.

Lopez-Larson MP, DelBello MP, Zimmerman ME, Schwiers ML, Strakowski SM (2002). Regional prefrontal gray and white matter abnormalities in bipolar disorder. Biol Psychiatry 52: 93-100.

Lyoo IK, Kim MJ, Stoll AL, Demopulos CM, Parow AM, Dager SR et al (2004). Frontal lobe gray matter density decreases in bipolar I disorder. Biol Psychiatry 55: 648-651.

Manji HK, Bebchuk JM, Moore GJ, Glitz D, Hasanat KA, Chen G (1999). Modulation of CNS signal transduction pathways and gene expression by mood-stabilizing agents: therapeutic implications. J Clin Psychiatry 60(Suppl 2): 27-39; discussion 40-41, 113-116.

Manji HK, Bersudsky Y, Chen G, Belmaker RH, Potter WZ (1996). Modulation of protein kinase $\mathrm{C}$ isozymes and substrates by lithium: the role of myo-inositol. Neuropsychopharmacology 15: 370-381.

Manji HK, Etcheberrigaray R, Chen G, Olds JL (1993). Lithium decreases membrane-associated protein kinase $\mathrm{C}$ in hippocampus: selectivity for the alpha isozyme. J Neurochem 61: 2303-2310.

Miki M, Hamamura T, Ujike H, Lee Y, Habara T, Kodama M et al (2001). Effects of subchronic lithium chloride treatment on Gprotein subunits (Golf, Ggamma7) and adenylyl cyclase expressed specifically in the rat striatum. Eur J Pharmacol 428: 303-309.

Mori S, Tardito D, Dorigo A, Zanardi R, Smeraldi E, Racagni G et al (1998). Effects of lithium on cAMP-dependent protein kinase in rat brain. Neuropsychopharmacology 19: 233-240.

Mork A (1993). Actions of lithium on the cyclic AMP signalling system in various regions of the brain - possible relations to its psychotropic actions. A study on the adenylate cyclase in rat cerebral cortex, corpus striatum and hippocampus. Pharmacol Toxicol 73(Suppl 3): 1-47.

Mork A, Geisler A (1995). Effects of chronic lithium treatment on agonist-enhanced extracellular concentrations of cyclic AMP in the dorsal hippocampus of freely moving rats. J Neurochem 65: 134-139.

Morri H, Ozaki M, Watanabe Y (1994). 5'-Flanking region surrounding a human cytosolic phospholipase A2 gene. Biochem Biophys Res Commun 205: 6-11.

Moser M, Ruschoff J, Buettner R (1997). Comparative analysis of AP-2 alpha and AP-2 beta gene expression during murine embryogenesis. Dev Dynam 208: 115-124.

Nemenoff RA, Winitz S, Qian NX, Van Putten V, Johnson GL, Heasley LE (1993). Phosphorylation and activation of a high molecular weight form of phospholipase A2 by p42 microtubuleassociated protein 2 kinase and protein kinase C. J Biol Chem 268: 1960-1964. 
Ozaki N, Chuang DM (1997). Lithium increases transcription factor binding to AP-1 and cyclic AMP-responsive element in cultured neurons and rat brain. J Neurochem 69: 2336-2344.

Rajkowska G (2002). Cell pathology in bipolar disorder. Bipolar Disord 4: 105-116.

Rapoport SI, Bosetti F (2002). Do lithium and anticonvulsants target the brain arachidonic acid cascade in bipolar disorder? Arch Gen Psychiatry 59: 592-596.

Rintala J, Seemann R, Chandrasekaran K, Rosenberger TA, Chang L, Contreras MA et al (1999). $85 \mathrm{kDa}$ cytosolic phospholipase A2 is a target for chronic lithium in rat brain. NeuroReport 10: 3887-3890.

Saluja I, O'Regan MH, Song D, Phillis JW (1999). Activation of CPLA2, PKC, and ERKs in the rat cerebral cortex during ischemia/reperfusion. Neurochem Res 24: 669-677.

Schibler U (1998). Circadian rhythms. New cogwheels in the clockworks. Nature 393: 620-621.

Siuciak JA, Lewis DR, Wiegand SJ, Lindsay RM (1997). Antidepressant-like effect of brain-derived neurotrophic factor (BDNF). Pharmacol Biochem Behav 56: 131-137.

Soares JC, Chen G, Dippold CS, Wells KF, Frank E, Kupfer DJ et al (2000). Concurrent measures of protein kinase $C$ and phosphoinositides in lithium-treated bipolar patients and healthy individuals: a preliminary study. Psychiatry Res 95: 109-118.

Stambolic V, Ruel L, Woodgett JR (1996). Lithium inhibits glycogen synthase kinase-3 activity and mimics wingless signalling in intact cells. Curr Biol 6: 1664-1668.

Stella N, Estelles A, Siciliano J, Tence M, Desagher S, Piomelli D et al (1997). Interleukin-1 enhances the ATP-evoked release of arachidonic acid from mouse astrocytes. J Neurosci 17: 2939-2946.

Sun GY, Xu J, Jensen MD, Simonyi A (2004). Phospholipase A2 in the central nervous system: implications for neurodegenerative diseases. J Lipid Res 45: 205-213.
Lithium's effect on CPLA $_{2}$ transcription factors

JS Rao et al

Teixeira NA, Karniol IG (1982). The influence of age and sex on weight variation in rats treated chronically with lithium chloride. Acta Pharmacol Toxicol (Copenh) 51: 1-5.

Wang HY, Friedman E (1996). Enhanced protein kinase C activity and translocation in bipolar affective disorder brains. Biol Psychiatry 40: $568-575$.

Wang HY, Friedman E (1999). Effects of lithium on receptormediated activation of $\mathrm{G}$ proteins in rat brain cortical membranes. Neuropharmacology 38: 403-414.

Wang HY, Johnson GP, Friedman E (2001). Lithium treatment inhibits protein kinase $\mathrm{C}$ translocation in rat brain cortex. Psychopharmacology (Berl) 158: 80-86.

Watson DG, Lenox RH (1996). Chronic lithium-induced downregulation of MARCKS in immortalized hippocampal cells: potentiation by muscarinic receptor activation. J Neurochem 67: 767-777.

Weerasinghe GR, Rapoport SI, Bosetti F (2004). The effect of chronic lithium on arachidonic acid release and metabolism in rat brain does not involve secretory phospholipase $\mathrm{A}(2)$ or lipoxygenase/cytochrome P450 pathways. Brain Res Bull 63: 485-489.

Weerasinghe GR, Seemann R, Rapoport SI, Bosetti F (2003). Lithium chloride, administered chronically to rats, does not affect the fractional phosphorylation of brain cytosolic phospholipase $\mathrm{A}(2)$, while reducing its net protein level. Brain Res Bull 59: 303-306.

Xu J, Weng YI, Simonyi A, Krugh BW, Liao Z, Weisman GA et al (2002). Role of PKC and MAPK in cytosolic PLA2 phosphorylation and arachadonic acid release in primary murine astrocytes. J Neurochem 83: 259-270.

Yuan P, Chen G, Manji HK (1999). Lithium activates the c-Jun $\mathrm{NH} 2$-terminal kinases in vitro and in the CNS in vivo. J Neurochem 73: 2299-2309. 